\title{
Legitimisation of Social Economy Entities: Theoretical Framework for Analysis in Polish Conditions
}

Małgorzata Marzec* ${ }^{\star}$ https://orcid.org/0000-0002-6833-554X

Abstract

*Jagiellonian University, Cracow, Poland. Email: malgorzata.marzec@uj.edu.pl

Background. In the literature one can find studies on the legitimacy of the political system or institutions (organs) of power. There are no studies on legitimacy from the point of view of social economy entities. Social perception is a factor that influences the success of social economy entities.

Research aims. The author set out to adapt the conceptual (semantic) apparatus to the analysis of legitimacy in relation to institutions operating in the social economy sector.

Methodology. The article has a theoretical character and presents the importance of the concept of legitimacy in the environment of social entrepreneurship (conceptual paper). The thesis the author will try to prove is that legitimisation of social economy entities is an essential element of the functioning of the social sector. The analysis was made on the basis of Polish conditions.

Findings. The analysis of planes and factors shaping the legitimacy of social economy entities seems interesting. Summarising the results of the research, it can be seen that the category of legitimacy, combined with the acceptance and legal validation of the activities of individual entities, as well as the entire social economy system, can be useful.

Keywords

social entrepreneurship, legitimation, social economy sector.

\section{Introduction}

This paper presents the theory of legitimacy and its application to the social economy sector. It attempts to adjust the conceptual apparatus of the theory of legitimacy, which looked at social entrepreneurship from a different perspective. The first part of the article, by way of an introduction to the subject matter, presents theories of legitimacy, describing the basic concepts, categories, and meaning of legitimacy. A review of legitimacy theories made it possible to identify potential areas of analysis (research) of the social economy sector based on legitimacy theory. The second part presents a discussion on the principles of functioning of the social economy sector in Poland. The analysis of the social economy sector was supplemented by methods of presentation and evaluation of the activities carried out by social economy entities in Poland. For the sake of this article, it was assumed that the application of the theory of legitimacy may enrich research on the social economy sector, contributing to the understanding of processes that take place both in social economy entities and around them. Due to the described difficulties in evaluating the performance of social economy entities, other criteria were proposed for assessing the performance of social economy entities from the perspective of acceptance of standards of a given society. The conclusions made it possible to show the author's way of analysing the meaning of information provided by social economy entities as a tool for building legitimacy of social economy entities with indication of the determinants of the directions of its creation.

In the analysis of social entrepreneurship, the concept can be explored on two levels. One refers to the institutional space, in terms of key actors influencing the functioning of such entities. The other presents the conditions of the functioning of entities by describing projects supporting the development of social entrepreneurship. There are no analyses related to the acceptance, authorisation, or expectation with regard to the scope of activity of social economy entities.

The aim of this paper is to indicate the possibility of using the concept of legitimacy to evaluate the activity of social economy entities and indicate recommendations that may be helpful in creating new tools for assessing the activity of social economy entities. A number of research methods were used in the study. A literature review was carried out on the scope of legitimacy

+ Corresponding author 
theories, definition of the social economy sector, and methods and tools for evaluation of social economy entities. The paper presents the characteristics of the Polish social economy sector, using statistical data, analysis of legal acts, and reports provided by social economy entities. The applied descriptive and comparative methods made it possible to draw conclusions and develop a new perspective on social economy entities in terms of legitimacy and effectiveness of action.

\section{The theory of legitimacy: An attempt to adapt it to the social economy sector}

The theory of legitimacy is based on the assumption that the functioning of an entity is a kind of social contract aimed at obtaining and maintaining social acceptance. The term social contract is difficult to define, but it can be assumed to mean a wide range of society's expectations, both hidden and clear, about how an organisation should operate (Deegan \& Unerman, 2011, p. 325). The idea of a social contract was analysed by various researchers (Cooper, 2004, p. 25). Each institution operates in the society on the basis of a social contract based on providing socially desirable results of activity to the wider society. A social contract distributes economic, social, or political benefits to groups that create conditions for the functioning of various actors. (Deegan \& Unerman 2011, p. 327; Krasodomska, 2013, p. 44).

Legitimacy is an interdisciplinary concept, addressed by a number of sciences, including sociology, the theory of state and law, political science, law, political system history, and social psychology. The first mentions of the concept of legitimacy can be found even in ancient times. The term legitimacy comes from the Latin word legitimus, meaning lawful, and should be associated with the word legitimo (Winczorek 1985, p. 66) The Dictionary of the Polish Language defines the term as "giving legal force" or "considering a political system to be the most appropriate for a given type of society." It is placed in the context of the legitimacy of power (Dictionary of the Polish Language). It seems important to separate the notion of legitimacy understood as a certain state of the system (usually a political system) from legitimacy combined with the process that leads to this state. In the literature on the subject, legitimacy is used interchangeably with the terms legitimation, legitimisation, sanctioning, legal validity, and lawfulness. (Marzec \& Szczudlińsk-Kanoś, 2019)

Changes in the approach to analysing the legitimacy problem have been recorded throughout the years. Initially, legitimacy was treated in traditional doctrine, with reference to various criteria of legal validity. The liberal theory of the legitimacy of power was the next to be developed. The theory indicated legitimacy was only legally valid for the power capable of ensuring broad participation of citizens in the government and meeting with their support (Lipset, 1959, p. 77; Sokół, 1995, p. 18). Another concept is combined with the so-called "belief." A legitimate system exists only when at least a part of the population ("active minority") considers it "valid," while other groups are unable to provide an alternative to the "promoted" mode of action (Kosturbiec, 2001, p. 3).

Legitimacy is combined with the power to act as well as the sanctioning of the action, which leads to assigning legal force to an activity. Legitimacy provides an opportunity for a generalised perception or assumption that the actions of the entities concerned are desirable, appropriate, and relevant in a certain socially constructed system of norms, values, beliefs, and definitions (Suchman, 1995, p. 574; Deephouse \& Suchman, 2008, p. 51-52; Zysnarska-Dworzak, 2015, p. 183). Legitimacy in relation to the organisation is a result of its subordination to social norms and laws (Zysnarska-Dworzak, 2015, p. 183).

All organisations, on the one hand, influence society, and on the other, are themselves influenced by it. The analysis of the organisation and society from the perspective of the system allows for the separation of determinants that are important in relations between organisations, the state, individuals, and entire communities. The interaction of organisations as part of the social system is becoming increasingly important. These relationships can be presented by means of system-oriented theories (Deegan \& Unerman, 2011, pp. 320-21). The literature highlights the following theories: the legitimacy theory, the stakeholder theory, and the institutional theory. Due to the thematic scope of the paper, only the theory of legitimacy shall be presented. According to Gray et al. (1996, p. 47, qtd. Deegan \& Unerman, 2011, p. 322) the theory of legitimacy stems from the broader political economy theory, according to which the activities undertaken by people must be analysed in a broader perspective of political, social, and economic structures. The indicated planes are inseparable and influence each other. The theory of legitimacy is based on the belief that an entity influences the society in which it functions and the entity itself is subject to social influences. The theory of legitimacy assumes that an entity acts in such a way as to be perceived as operating within the boundaries and standards of the societies in which it operates. In the case of social economy entities, this should be extended to include additional tasks performed within society by such entities, and in particular the social impact of these entities. Social economy actors are required to constantly prove that their actions are based on social acceptance. Conduct that is not in line with the social contract may lead to sanctions imposed by society on a given entity, either in the form of formally defined restrictions on the entity's activity or of limitation with regard to the resources needed (e.g., capital), or a reduction in demand for its products 
(e.g., in the form of not using certain services, etc.). In the case of social economy entities, it may be extended to include a reduction or lowered interest in various forms of involvement in the activities of entities operating in the social economy sector (lack of involvement in social or charitable activities). The entities take various types of actions aimed at ensuring legitimacy, trying to bring about the compatibility between the social values created as a result of their activities, and the standards of conduct accepted by the society as a whole.

According to Matuszak, an organisation can function to the extent legitimised by society (Matuszak, 2015, pp. 112-34). Legitimacy is not only analysed as a resource or commodity, but also as a phenomenon determining the existence of a given entity. Obtaining legitimacy by an entity is related to social acceptance of its activities and achievements. Two types of legitimacy can be distinguished: strategic and institutional (Chodyński, 2017, pp. 13-16). Institutional legitimacy emphasises the relationship between the organisation and its environment, as well as the conditions of the activities undertaken by said organisation through the perspective of the external community or environment. This type of legitimacy manifests itself in the adaptation of the entity's activity to socially accepted norms, values, and beliefs. Institutional legitimacy is linked to the adoption of a perspective of an external institution and society - society looking in. This is connected with the focus on the conditions under which decisions are made as a result of the influence of the environment in which the institution operates. However, cultural pressure, including the system of values and beliefs in force, is also of importance (Łada, 2015, p. 167; Oliver, 1991; Suchman, 1995, p. 572). Strategic legitimacy, on the other hand, is considered an internal process aimed at the external environment - managers looking out. A strategic perspective on legitimacy assumes that legitimacy can be shaped in order to achieve the intended results of the organisation. Strategic legitimacy is related to the undertaking by the entity of activities aimed at gaining and maintaining social acceptance, primarily that of external stakeholders (Łada 2015, p. 112). In research literature, this type of legitimacy is presented as an operational resource of an entity, which, separated from the environment, allows it to achieve its objectives (Pfeffer, 1981, p. 5). Separation of the two approaches to legitimacy makes it possible to analyse this category in different entity orientations, i.e., internal and external (Łada \& Kozarkiewicz 2013, p. 167). Internal (strategic) orientation involves undertaking various activities as a result of which a system or an organisation is to maintain or obtain social support and acceptance for its activities. The external (institutional) orientation focuses on the external conditions of the decisions made. It is assumed that decisions related to the functioning of a system or entity are conditioned by external factors, its structure, the relevant cultural norms, and the system of values and beliefs (Jastrzęboska, 214, p. 50). Particularly in the case of the social economy system, it is important to shape the orientation of institutional legitimacy.

Legitimacy is a concept presented on different levels. Based on the literature, several levels of legitimacy analysis can be identified, that is:

- Legitimacy, as a claim against the state (system)

- Legitimacy, as acceptance of claims against the state (system; faith in legitimacy)

- Legitimacy, as justification for rulers, for their special position and preference in accessing special values, rights and privileges

- Legitimacy, as a promise that the system will contribute to the needs of different social groups

(Beetham, 1991, p. 15; Żyłomski, 2012, p. 19)

Each of the indicated levels is justified when analysing the social economy system from the point of view of the legitimacy of its activities. Regardless of the approach to the problem, it should be noted that legitimacy is the recognition by subordinate groups of existing relationships of dependence (power) as acceptable. This should lead to recognition of the decisions and actions of the governing groups as worthy of observance or support and of the system and its institutions as worthy of trust and confidence in the achievement of results. Acceptance seems to be an essential element in building a legitimate system of social economy. However, it should be remembered that acceptance presupposes voluntariness and awareness, as it should result from knowledge and evaluation of the functioning of a given system. Compulsion and unawareness rule out acceptance which in fact is nothing more than obedience to the system. It seems important to shape legitimacy as supported by social acceptance.

There are three levels of legitimation analysis, i.e., pragmatic, moral, and cognitive. (Suchman, 1995, p. 580; Matuszak, 2015, p. 120) All three complement each other, but at the same time make it possible to analyse the social acceptance of an organisation through the prism of various mechanisms. Pragmatic legitimation is based on the perception of the subject's own goal of action by both sides of the relationship, i.e., by a given institution and entities from the external environment. It is based on the exchange of information provided, on the impact on the environment (society), and on availability (the possibility of carrying out specific tasks). Moral legitimation is considered as the procedural, structural, and personal legitimation of results. After all, cognitive legitimisation is related to human cognitive processes and is based on human understanding of organisation. This type of legitimation may take place as creating a certain deliberate image of the organisation or as creating a template that gives positive or negative meanings 
to specific activities (the so-called unquestioned legitimisation). In the case of social economy entities, it seems important to develop pragmatic and cognitive legitimacy, especially in terms of unquestionable legitimacy.

Legitimacy is a complex phenomenon of a multidimensional character (Beetham, 1991, p. 15; Żyłomski, 2012, p. 19). Not only the way of gaining acceptance is important, but also the methods used to gain public support. The question is: to what extent is the system or entity legitimised? What has caused it to gain legitimacy, and what is the significance of this? Approximation of this problem should become the basis for analysing the legitimacy of the social economy system, in particular the entities operating within this system. The legitimacy process should be considered at three closely related levels, i.e., the level of principles, justification, and action (Beetham, 1991, p. 3; Żyłomski, 2012, p. 10). A legitimate system should "be based on just principles, justified by a high substantive assessment of the quality of those in power, and the exercise of power itself should be in line with social expectations" (Żyłomski, 2012, p. 19). Legitimacy can be understood as a regulatory norm (imposed, semi-imposed) that induces certain behaviours, or as an internalised conviction of the society (the subordinates) that the norm is not only mandatory, but also for rational or emotional reasons — "just." The indicated conviction should correspond to the subject of colloquial beliefs; it should be consistent with the perception of reality or correspond to values that people would like to follow themselves (Wesołowski, 2001, p. 557).

A review of literature on legitimacy allows us to draw attention to three essential elements related to this concept. First of all, legitimacy is the process by which an entity justifies its right to exist, and the result of this process (Łada \& Kozarkiewicz, 2013 , p. 166). Second, the essence of legitimacy is to ensure that the norms and values associated with the entity's actions are compatible with the values and norms acceptable in the society in which it operates. Third, a variety of goals can be set to achieve legitimacy (Suchman, 1995, pp. 573-74; Ogden \& Clarke, 2005, p. 314; Durocher \& Fortin, 2010, pp. 479-80; Beuren \& Boff, 2011, p. 61). What is important is that legitimacy provides a positive image of the entity and social trust in its activities. Legitimacy may apply to the whole organisation, as well as to its individual aspects. The importance of legitimacy can be analysed in several ways. It can be presented as an organisational resource that facilitates relationships with different stakeholders (resource-based view). This enables stakeholders to see the organisation's activities as relevant, legitimate, and justified. Legitimacy can also be analysed as a mechanism regulating the transmission of socially binding norms and standards and organisations supporting and introducing social norms as supporting the relevance of legitimisation processes (Łada \& Kozarkiewicz, 2013, p. 166).

Organisational legitimacy is shaped by a number of factors. On the one hand, these depend on the environment in which a given entity operates; on the other hand, the actions taken by said entity shape the process of building legitimacy. Gaining legitimacy can be supported by a variety of mechanisms. Suchman points out several mechanisms to support the process of building legitimacy, that is:

- Appropriate choice of the institution's operating environment, which will accept or support its activities, guaranteeing appropriate public support for the activities undertaken

- Manipulating the external environment by means of appropriate information provided on the entity's operating principles, objectives, and results (effects) of its activities

- Conformist mechanisms, i.e., those related to confirming the conformity of the organisation's own system of norms and values with the requirements of external institutions, which is connected with the presentation of the entity's activity according to specific rules mandatory in a given environment of standards of task performance

(Suchman, 1995, pp. 587-91).

The theory of legitimacy makes it possible to seek ways to explain an organisation's conduct and, what is important, does not impose any specific conduct on an organisation, but rather describes it as part of a wider social system in which it cooperates and is at the same time influenced by a number of social groups. Social economy entities, similar to other institutions operating within society, are an element of the social system. It can be argued that these entities in particular should have a high level of legitimacy, due to the scope of tasks and functions performed. The theory of legitimacy assumes that external stakeholders expect organisations to take actions that allow the stakeholders to assess the organisations' conduct as transparent, compliant with the law, but also as adequately satisfying the needs of society. One of the important issues here is how to present and evaluate the activities undertaken by social economy entities. Social sector actors should disclose information about their activities to create conditions for assessing their activities. There is no consensus as far as the methods and tools for assessing the activities of social economy entities are concerned. Such an assessment should be made not only on the basis of the economic (financial) categories, but also by establishing the interaction of a given entity with its environment.

In conclusion, the difficulty of formulating a single definition and the multifaceted nature of the problem of legitimacy are worth highlighting. On the basis of the literature review, it can be concluded that the legitimacy of the social economy system means the acceptance of its activities, supported by properly prepared social communication, processes of teaching attitudes, 
and values, combine to grant it legitimacy. The social economy system only needs to convince the majority of citizens of its legitimacy, regardless of its mode of operation. It has been pointed out that it is possible to grant legitimacy to the government (here the social economy system) if the procedures applied and the outcome of the activities were awarded with a positive moral evaluation (Kosturbiec, 2001, p. 10). In the case of the social economy system, it seems that a social conviction that the system operates according to certain procedures (and that the outcome of the activities of the entities operating within the social economy system do so) will ensure an appropriate social effect (social benefits) is necessary. Social economy actors will provide products or services that will respond to specific social expectations or have a relevant social impact. It seems necessary to indicate the importance of legitimacy against the background of the conditions of the social entrepreneurship system in Poland. The subsequent parts of this paper present the principles of operation of the social economy sector and review the methods of assessing the activity of social economy entities in Poland.

\section{Definition and scope of activity of social economy entities in Poland}

The manner in which contemporary societies function requires the existence of a separate sector called social economy. The social economy finds its place between three planes: civil society, market, and state (Hausner, 2008, pp. 12-13). All three planes are complementary to each other but are based on different allocation and relationship rules. Economic and social phenomena are accompanied by positive and negative social effects, which affect the social policy of the state and socio-economic concepts in the background with emerging problems of market or non-market allocation. Under these conditions, a certain part of the population is excluded and marginalised. The reason for marginalisation of groups may be temporary (e.g., unemployment), personal (e.g., lack of resourcefulness), biological (e.g., illness or disability), or fortuitous (e.g., flooding). It should be in the interest of society as a whole to organise aid for excluded groups. The state has the opportunity to mitigate the negative effects of economic relations by creating conditions and supporting the development of the non-governmental social economy sector (Płonka, 2015, pp. 85-86). The task of the social economy sector is to use various forms of market redistribution and allocation in solving social problems. Particularly important here are various forms of cooperation based on the idea of self-help and reciprocity, and in groups at risk of poverty, learned or acquired impotence, social exclusion, and marginalisation (Płonka, 2015, pp. 97-98). In developed societies, redistribution can be made by both the public sector (budget, local government units) and the private sector (grants, donations, or other forms of social and charitable activity). In the social area, market allocation requires organisational and financial effort and often involves economic risk. Emerging organisations related to the social sector create conditions for the elimination of areas at risk of marginalisation and may contribute to the creation of new social value. In addition, social sector organisations can limit the development of social pathologies and accelerate and harmonise the social and economic development of the society as a whole, as well as bring benefits in the long term (Płonka, 2009, pp. 207-16). The social economy sector creates the conditions for sustainable development, job creation, and the generation of wealth used by society as a whole. It is a sector that is able to combine profitability with social inclusion within the socio-political system and work in the private and public sector, providing services that are socially needed (adapted) (Goleński, 2017, p. 7).

There is no consensus in the literature on the scope of activity of the social economy sector. In addition, quite a bit of chaos can be found in the definitions of the sector and the different actors in the sector. A number of concepts connected with the social economy sector can be found in the literature: "civil society," "the third sector," "non-governmental organisations," "non-profit organisations," "charities," etc. (Grassl, 2012, p. 37). Terminological ambiguity makes it difficult to understand the essence of social economy as a sphere of society-oriented economic activity. A. Etzioni's classic concept states that the third sector comprises a community separate from the state and commercial (market- related) sectors (1973, p. 320). The basis of a sector defined in such a way is the voluntary engagement of individuals, based on common values, based on various forms of communication. To distinguish institutions operating in the social economy sector, the concept of non-profit entities was introduced. ${ }^{1}$

Third-sector actors are closely linked to both the private and public sectors. From a formal point of view, the social economy sector is a private-public sector, characterised by diverse organisational and legal forms aimed at fulfilling the social mission in diverse operating environments. The principles of operation of social economy entities evolved over time and their operating conditions depend on changes in external conditions. In the CEP-CMAF Charter signed in Brussels on 10 April 2002 , the social

\footnotetext{
${ }_{1}$ According to the definition of the United Nations Statistics Division, the non-profit sector includes entities formalised (registered); institutionally separate from public administration, constituting the non-governmental organizations (NGOs); operating for reasons other than profit and not distributing any surplus among its members, employees, etc.; self-governing (with internal bodies and a specific purpose); characterised by voluntary participation in the organization's activities and significant participation of volunteers (Handbook on Non-Profit Institutions in the System of National Accounts, pp. 6-7).
} 
economy sector is defined as "social and economic actors active in all sectors, distinguished by their objectives and specific form of entrepreneurship...such as cooperatives, mutual societies, associations and foundations" (CEP-CMAF, 2005, p. 9). Different positions concerning the scope of activity of social economy entities result from the fact that the social economy combines with various spheres of activity of the public sector, non-profit organisations and philanthropy, volunteering or charity, but also with elements of business activities (Urbano et al., 2010, p. 54; Goleński, 2017, p. 9). Social economy entities adopt diverse forms of activity, which results from the traditions and legal and political conditions of individual countries (Frączek et al., 2012, p. 71; Goleński, 2017, p. 9). The most important thing is that social economy entities are organisations oriented on social utility, and what is important, the surplus accumulated in the course of activity can be used to achieve the social objective set by the entity. According to W. Kwaśnicki, when juxtaposing different definitions of social economy, all terms emphasise a few values: solidarity, social cohesion, social involvement and responsibility, democracy in participation, autonomy, and independence (Kwaśnicki, 2005, p. 16). An important premise for the development of social economy entities should be the solidarity of members, a well-recognised local market, and adaptation of the local environment to its needs. Social economy entities cannot operate effectively without public support and acceptance of their activities in the local community.

The specificity of a given country or region influences the scope of the subject, determining the institutional framework and the possibilities of operation of social economy entities. ${ }^{2}$ Two approaches to analysis of social economy dominate in literature: institutional and functional. The institutional plane defines the sector, assigning certain society-oriented forms of entrepreneurship to it. The functional approach defines social economy entities from the perspective of their specific functioning and operating principles. This criterion can be used to distinguish social economy market entities and integrative entities (Stanienda et al., 2017, p. 40). The Polish social economy sector is defined by civic and social activities, conducted in the form of economic and public benefit activities, and serves the professional and social integration of people at risk of social marginalisation. Civic involvement aims at creating jobs and providing social services of general interest (for the general public) and local development (KPRES, p. 13). ${ }^{3}$

The social and solidarity economy does not significantly affect the Polish economy, both from the perspective of its share in the GDP and the level of employment in this sector. In addition, there is still a relatively low level of trust and knowledge of how social economy actors operate. Low knowledge of the effectiveness of social economy entities, low level of promotional activities concerning products and services offered by those entities, as well as activities showing the benefits resulting from activities of such entities, all result in lowering the potential of joint social activity to undertake initiatives in both the economic and the social sphere. In turn, the lack of appropriate knowledge and the small scope of social economy entities' activity results in low acceptance of the social enterprise sector, which limits the scope of social and economic involvement in the development of the social economy sector. It seems that development of legitimacy can be an effective way to condition the development of the economic sector.

\section{The scope of information enabling assessment of the activities of social economy entities}

Social economy entities operate in a number of areas of the economy, offering different products or services on different terms. The existence of this type of entity is determined mainly by the implementation of social objectives, which dominate over economic objectives. However, the activities of the social economy entities should be evaluated in terms of the achievement of social objectives in conjunction with economic efficiency. This raises some questions: How should activities of social economy

\footnotetext{
2 The social economy sector has existed in Poland since the 1990s. The basic legal act defining the formal and organisational scope of activities of third-sector organisations is the Act on Public Benefit Activity and Volunteering. Art. 3 of the above mentioned Act defines non-governmental organisations as entities that are not units of the public finance sector (separation from the public sector) and entities not operating in order to achieve profit (non-profit character), but having legal capacity granted on the basis of relevant provisions (formal character) (Kwaśnicki, 2005, p. 20). In Poland, there is no single legal act defining the legal framework of the functioning of social economy entities. Legal standards regulating the status of social economy entities concern, among other things, the rules of operation of associations, foundations, cooperative savings and settlement societies, or social employment rules, etc., and cover 14 legal acts (Stanienda et al., 2017, p. 37 ; www.ekonomiaspołeczna.pl). The social entrepreneurship sector is supervised and managed by the Ministry of Labor and Social Policy, which developed the National Programme for Social Economy Development (KPRES) until 2023 (KPRES, p. 13).

3 The 2019 National Social and Solidarity Economy Program has characterised Polish social economy entities by indicating common features and principles identifying various entities operating in the field of the social economy. In order to be included in the social economy sector, an entity must be characterised by the following operating principles:

- primacy of social goals over economic goals

- giving priority to the provision of services to members, employees or the community over categories of absolute profit

- autonomous management and participatory decision making

- conducting activities on a regular basis based on economic instruments and bearing economic risk in connection with this activity

(Monitor Polski 2019, item 214, p. 13).
} 
entities be evaluated? Is it possible to use tools (methods) used by other actors in the assessment of social economy entities? Or should other ways of assessing their activities be sought? According to Głowacki et al., measuring the effects of social economy entities poses some difficulties due to the fact that "traditional indicators used to assess the effectiveness of companies fail in this respect, as they focus on measuring their value generated within the entity and expressed in money (revenue, income, profit)" (2012, p. 327; see also Łącka, 2015, p. 244). When assessing the activity of social economy entities, tools should be used to determine both the financial value of the entities and products and services provided and the categories to determine the social effects of activity (the concept of social added value can be indicated). A wide range of organisational forms operating in the social economy sector makes it difficult to carry out research, but this does not mean that analyses of individual entities operating in the social economy sector should be abandoned - quite the contrary. It is necessary to assess the performance of the entities by examining whether the objectives were achieved, whether the problems for which the entity was established were resolved, and whether the needs of the beneficiaries were met. It is also necessary to determine whether an entity has an impact on solving social problems in the short and long term, to what extent it has done so, and what results from the entity's action for the wider community (Juraszek-Kopacz \& Tyrowicz 2008; Stiglitz et al., 2009; Zahra et al., 2009; Łącka, 2015, p. 244) There has been a discussion in the literature for some time on the criteria for evaluating social economy entities' activities. There is a terminological ambiguity in the area of evaluation, measurement, and influence of the social sector. Against the background of activity of all economic entities operating in the economy, social economy entities are distinguished by the priority of social objectives over economic ones. The social economy sector provides products or services that fill a gap in the market in areas where traditional operators do not operate due to insufficient profitability. The entities operating in the social economy sector, like other entities, need resources to carry out their statutory activities and incur costs in the course of performing their tasks. Two main directions of development of social economy institutions can be distinguished from the point of view of economy analysis: rationalisation of management of the resources held, i.e., socialisation of economic objectives, or economisation of social objectives (Płonka, 2015 p. 41). The given criterion for distinguishing social economy institutions is quite important because of social and economic objectives implemented by social economy entities. Social enterprises are those that carry out business activities or paid statutory activities and transfer their surplus to social purposes. The CEPCMAF's Charter of Principles of the Social Economy states that the success achieved by social economy actors cannot be measured solely in terms of their economic performance, and although it must not be overlooked, it should also be assessed in terms of their contribution to solidarity, cohesion, and territorial ties (www.cepcmaf.org).

Due to the degree of economisation of social economy entities, a distinction can be made between non-profit organisations (social organisations) and not for profit organisations (social enterprises). The non-profit term suggests that the activities of these entities are based on redistribution. The term of not for profit assumes that an entity should achieve a financial surplus (revenues should exceed costs) due to its activity, however, profit is a means to achieve the social mission and not an objective in itself. Two types of entities can be distinguished here. The first type of entities for which economic activity is the main source of income and social activity is marginal (e.g., cooperative banks, mutual societies, etc.). The second type includes organisations for which economic or statutory paid activity is a secondary source of income (e.g., associations, foundations, trade unions, etc.). All social economy organisations are, by definition, geared toward meeting the social or personal needs of individual members of the organisation.

The prepared reports (financial statements and factual reports) provide reliable knowledge on the activities of individual social economy entities. They allow determination of the extent of the assets at their disposal, the amount and structure of the sources of financing, and the structure of the revenue generated in combination with the costs necessary to achieve the intended objectives. Factual reports make it possible to assess revenues, costs, employment structure, investments made, and cooperation with governmental and local government entities. This provides a basis for evaluating the activities of individual entities. However, information provided to stakeholders on the scope of activities of social economy actors is not uniform for all actors and, more importantly, may be misunderstood by the majority of recipients.

Society should believe that social economy actors perform tasks in accordance with social expectations. The social economy system should inspire the belief that for rational or emotional reasons its functioning is "right" and corresponds to the values that people would like it to follow. Legitimacy can enable stakeholders to see the activities of an organisation as relevant, legitimate, and justified. An important element of legitimacy building is the process of providing information on the scope of activity, objectives of an organisation, and effects of the activity determined on the economic and non-economic levels (mainly in terms of social impact).

Social economy entities are seen both as a praxis sphere and a research sphere. In practical terms, the social economy sector is analysed as a mechanism for the provision of goods and services within the existing social and economic order, which cannot be separated from the effectiveness of the activities of the organisations that are part of it and its impact on society 
(Goliński, 2017, p. 8; Borzaga \& Tortia, 2007, p. 25). Researchers are often confronted with a fundamental question: How can the activities of social economy actors be evaluated, and what criteria should be used? For some time now, there has been a discussion on the study of the effectiveness of social economy entities. In order to propose a different view of the social economy entities activities, the next section will present the category of effectiveness in relation to social economy actors.

\section{Effectiveness of social economy entities: A step toward legitimacy}

Effectiveness is a complex concept. ${ }^{4}$ The table below lists the terms used in effectiveness studies. Effectiveness is considered by many authors a controversial category and at the same time the most important in terms of valuation. Effectiveness is compared to performance and efficacy (Supernat, 2005, p. 174). In turn, the term "performance" means well-functioning, wise use without unnecessary waste, and proper organisation. Performance analyses are considered on the basis of praxeology (Zieleniewski, 1981, p. 233). The concept of "effectiveness" is combined with the implementation of tasks successfully, with a desired, positive result and achieving success in the activities undertaken (Griffin, 2002, p. 38; Furtak-Niczyporuk \& Drop, 2013, p. 57). Effectiveness is a component of efficient action, besides being beneficial and economical, where an effective action is one that leads to the effect intended as an objective (Kotarbiński, 1982, p. 104).

Measurement of effectiveness is the subject of analysis in economic and management sciences. Effectiveness makes it possible to determine the consequences of actions and to assess the use of resources and the extent to which an action is consistent with the objectives for which it was taken. In economic sciences it is assumed that effectiveness is the ratio of effects (results) to efforts. Here, effectiveness is associated with performance. Performance, on the other hand, is defined as the scope or the extent to which the objectives are achieved. Economic effectiveness is "the result of the activity of an entity or a specific undertaking resulting from the relation between the achieved results and the incurred efforts" (Jastrzębska, 2016, p. 50). The effect may be measured qualitatively and/or quantitatively in relation to the objective of the action taken. Here, two methods of action can be indicated, assessed as effective, either "the maximum degree of achievement of an objective can be obtained with a given amount of resources (the greatest effect/the greatest efficiency principle) or the minimum amount of resources can be used with a given degree of achievement of an objective (the least cost/greatest saving principle)" (Jastrzębska, 2016, p. 50; Zieliński, 2013, p. 9).

In management science, effectiveness is combined with the ability of an entity to adapt to changes in its environment on an ongoing and long-term basis and to use its resources sparingly and productively to achieve its goals. Often, the term effectiveness is associated with the concept of performance, combined with effectiveness and benefit (cost-effectiveness),

Table 1. Terminology used in effectiveness studies

\begin{tabular}{|c|c|c|c|}
\hline Term & Synonym & Related terms & Definition \\
\hline effectiveness & $\begin{array}{l}\text { Efficacy, efficiency, rationality, profitability, cost- } \\
\text { effectiveness, productivity, performance }\end{array}$ & Optimal, efficient & $\begin{array}{l}\text { The ratio of the useful result to the effort incurred to } \\
\text { achieve said result. }\end{array}$ \\
\hline effective & $\begin{array}{l}\text { Effectual, rational, economical, profitable, } \\
\text { productive, beneficial, cost-effective, resultant }\end{array}$ & $\begin{array}{l}\text { Optimal, best, } \\
\text { adequate }\end{array}$ & $\begin{array}{l}\text { Positive (desired) result, but not necessarily the } \\
\text { highest effectiveness. }\end{array}$ \\
\hline optimality & Maximum state, minimum state & $\begin{array}{l}\text { Effectiveness, } \\
\text { rationality, productivity }\end{array}$ & Assumes only values above 1 or other than 0 . \\
\hline optimal & The best in terms of the criterion adopted & Effective & $\begin{array}{l}\text { A state where the objective function reaches an } \\
\text { extreme (max. or min.) at given constraints. }\end{array}$ \\
\hline Social effectiveness & $\begin{array}{l}\text { Effectiveness of social production, macroeconomic } \\
\text { effectiveness, objective effectiveness, allocation } \\
\text { effectiveness, management effectiveness }\end{array}$ & Economic efficiency & $\begin{array}{l}\text { The results obtained are beneficial for the economy } \\
\text { as a whole in terms of the expenditure incurred. }\end{array}$ \\
\hline cost-effectiveness & Management effectiveness & Social effectiveness & $\begin{array}{l}\text { Concerns measurable phenomena and processes } \\
\text { that can be shaped. }\end{array}$ \\
\hline Effectiveness of work & Work efficiency, labour intensity & $\begin{array}{l}\text { Effectiveness of } \\
\text { production, entity }\end{array}$ & The ratio of the work result to the workload incurred. \\
\hline
\end{tabular}

Source: Based on Czechowski (1997), p. 19.

4 The word "effectiveness" comes from Latin effectivus, which means potent (Słownik Wyrazów Obcych, p. 171). In the Polish language, the term means a positive result, efficiency, efficacy, capability (Słownik Języka Polskiego, p. 516). The problem with defining effectiveness is the existence of a multitude of synonyms of the word. The dictionary provides a list of synonyms that could be translated as follows: efficiency, performance, efficacy, capacity, rationality, operability, productivity, usefulness. The term has an identical meaning in English and a similar list of synonyms used interchangeably with it. (Pyszka, 2015, p. 16). 
where performance is associated with the pursuit of a result consistent with the objective. The benefit is determined by the relationship between the result and the effort incurred to achieve it (Penc, 1997).

The quantification of effectiveness usually comes down to measurement based on numerical values. However, the effectiveness of certain activities, especially those concerning social economy entities, is difficult to measure using classical economic methods, therefore other ways should be sought to define the effectiveness of their impact or effects. In the literature you can find effectiveness analyses compared with efficiency in economic terms, but also with performance and degree of preference (Pyszka, 2015, p. 17). At the end of the twentieth century, the concept of social entrepreneurship emerged, which did not cover all forms of social economy entities but was introduced to draw attention to the phenomenon of activities that combine social and economic objectives (Guo \& Bielefeld, 2014, p. 3).

Evaluation of the effectiveness of social economy entities should be multidimensional and also cover their non-financial (social) objectives. This requires a different approach as well as the development of different methods and criteria for measuring and assessing effectiveness, taking into account the specific conditions of social sector organisations. ${ }^{5}$ The assessment of the effectiveness of social economy actors should take into account the achievement of social objectives, the achievement of which is often long-term and non-financial. A uniform standardised measurement cannot be used, and attention must be paid to the achievement of social objectives when assessing the social economy entities. This raises the fundamental problem of quantifying social objectives. The dominance of non-financial objectives in social economy sector activities requires the definition and operationalisation of the concept of "social efficiency." It can be assumed that social effectiveness is expressed in the relation of effort (cost) to effect (benefit), which allows for the social mission to be carried out rationally by a given entity. A number of methods of assessing the activities of social economy entities can be found in the literature. The effectiveness of a social economy entity can be measured by comparing the outlays with the effects achieved (products, results, output). It provides a basis for analysis from the point of view of the invested funds. Effectiveness analysis in the economic sense is often complemented by the analysis of effectiveness of a social economy entity and the assessment of social impact, which the organisation exerts on its environment. The analysis of the impact of the social economy entities on the environment provides additional information, for the actors themselves and their donors, needed to decide on future courses of action, in terms of allocation of resources, but also related to the abandonment of certain programmes or projects, as they are assessed as ineffective and/or inefficient (Łacka, 2015, p. 245).

To summarise: "effectiveness" is the right thing done in the right way, where both performance and efficiency are important. Here, performance means doing things the right way, and efficiency means doing the right things (Stoner et al., 2001, p. 24). Effectiveness in relation to social economy entities should be combined with the efficiency or_performance of a given entity and can be a measure of the extent to which the organisation has achieved its goals through its social mission (Stoner et al., 2001, p. 24). However, the perception of social mission through the prism of narrowly understood effectiveness does not take into account all conditions of operation of social economy entities. Social economy entities not only provide services and products but can also create so-called social added value. This is another category difficult to quantify, as it indicates a group of effects resulting from the social economy entities activities, i.e., the awareness of joint decision-making, social ties, agency, or taking care of the environment, etc. (cf. Głowacki, 2010; Bohdziewicz-Lulewicz et al., 2012). When assessing the activities of social economy entities, the category of social impact (influence) should also be taken into account. It should be noted that this is a concept that overlaps with other categories in terms of meaning (definition). According to B. Juraszek-Kopacz and J. Tyrowicz the measurement of social impact allows one to assess both the effectiveness and efficiency of social economy entities and projects implemented by them (2008, p. 16).

5 Several key problems related to the assessment of the effectiveness of social economy entities can be distinguished:

- Diversified distribution of social and economic objectives in the sector, which implies a different approach to social activity in the hierarchy of objectives. The achievement of social objectives depends on the size of the financial surplus generated or the ability to obtain funds for statutory activity.

- The achievement of social objectives is less quantifiable and the period of return on social investments is longer than for commercial investments.

- The complementary nature of conducting business activity and generating revenues on this account implies a different distribution of risk of activity conducted by the social economy sector and forces the implementation of separate procedures for its assessment.

- The different sources of financing for the social economy sector, combining the characteristic features of the business sector (business activities, donations), the public sector (grants, subsidies) and the sector-specific features of this sector ("one percent," paid and unpaid statutory activity), imply a specific accounting treatment and scope of published financial information.

- The dominance of revenue characterised by low stability (e.g., membership fees, donations, and subsidies from public and private institutions and individuals) hinders long-term planning and reduces the credibility of an entity in the commercial environment.

- Low capacity to capitalise the potential of social economy entities is related to the fact that a possible financial surplus is used for the implementation of statutory objectives and not for the increase of assets, investments, which weakens the sector's potential for market competitiveness.

- The different and internally diverse structure of the sector's resources and capital makes it difficult to assess the credibility and compare the social economy entity to business entities with regard to typical procedures and standards (e.g., indicator analysis) (Płonka, 2008, p. 26-34). <Clarify which 2008 work, a, b, or c?> 
Diversified scope of activity and degree of economisation of social economy entities makes it difficult to determine a uniform system of effectiveness assessment. The main problem in assessing the effectiveness of the social economy sector is the inability to estimate, on the basis of existing financial and management reporting, the key components of social potential and impact, which often influences the underestimations of the values created by social economy entities and distorts the effectiveness of social projects. The presented methods and criteria for assessing the performance of social economy entities aim at estimating the social economy entities' activity based on various criteria adjusted to the specificity of the social economy system. It is difficult not to agree that the evaluation of actions taken by social economy actors should take into account the relationship between objectives, efforts (input), and results (output). To do this, organisational effectiveness should combine efficiency and performance criteria with the ability to adapt to changes in the environment on an ongoing and strategic basis (Szymańska, 2010, p. 152). It seems appropriate to extend the criteria for evaluation of social economy entities to include legitimacy of activities undertaken by social sector organisations.

\section{Effectiveness and legitimacy — a model for evaluating social economy entities}

The introduction of the concept of "legitimacy theory" may provide answers to two questions concerning the evaluation of social economy entities' activities. The first concerns the issue of the information gap. Is there a difference between how an entity perceives its activities and functioning and how it is perceived by its environment? Furthermore, consideration should be given to what measures could be taken to close the legitimacy gap through disclosure of information and communication with stakeholders. It seems important to provide relevant reports and activity reports. The second question concerns the organisational changes that should be undertaken by the social economy entities in order to meet social expectations in terms of meeting certain rules and standards applicable in the community.

The Polish reporting system, which applies to the activities of social economy entities, is characterised by information asymmetry, causing gaps in the perception of information by stakeholders. The following gaps can be identified here:

- An information gap relates to the difference between the levels of importance assigned to information received by users and the level of satisfaction of information needs (e.g., in Poland, there is a significant number of reports provided by PES for tax or financial reporting purposes, but the reports do not provide the information needed for all PES stakeholders).

- A reporting gap, that is, the difference between the importance of the assessment of individual quantities (categories) and the level of activity in reporting (e.g., in the case of PES regarding the detailed information on costs and revenues).

- A perception gap, that is, the difference between the meaning of information provided in reports and the possibility different recipients will use the data (e.g., reports lack information on the scope of social impact of social economy entities).

- A gap of understanding, that is, the difference between the information provided by the reports and the importance assigned to it by its users (e.g., information on the PES financial result).

The public perception of social economy entities' activity should be an important factor influencing the scope and success of the activity. Legitimisation is influenced by a number of variable factors concerning the organisation's environment as well as its intra-organisational relations. Social economy entities participating in social processes can gain legitimacy and, if necessary, can take actions to rebuild lost social acceptance. The subject of legitimacy management is tackled more and more frequently (Durocher \& Fortin, 2010). Social economy entities should undertake proactive actions aimed at convincing the society (citizens) and external environment institutions to undertake actions that shape legitimacy. The social economy entities approval should indicate the conditions necessary for the implementation of tasks by individual entities, as well as the functioning of the entire social economy system. The problem of acceptance (legitimacy) can be considered in terms of efficiency. Efficiency, in relation to social economy entities, should be understood as the logical relationship between the effect achieved and the objective pursued. According to S. M. Lipset (1959) four possible variants of the relationship between legitimacy and effectiveness (in terms of efficiency) can be distinguished (Figure 1). First, a high level of legitimacy provides a "reserve of extended support," which provides stability in the event of a decrease in the system's efficiency in meeting social needs (variant $a$ ). The efficiency of the system in meeting its objectives can be "bought" in a situation of stability of the system in exchange for the absence of legitimacy (variant $d$ ). High level of legitimacy, with low efficiency - variant $a$, after some time creates variant $c$, indicating system instability. Otherwise, a high assessment of the efficiency of the system, despite the low legitimacy threshold, should over time lead to variant $b$.

In the case of the social economy system, the best situation would be if its actions were effective and efficient with high legitimacy (variant $b$ ). Such a system seems to be the most stable, supported by public acceptance and approval of decisions 
made by entities (managers) in the social economy system. Lack of legitimacy may lead to civil disobedience, i.e., a situation in which, being convicted about injustice and inadequacy of the implemented solutions, individuals decide to express their opposition by consciously and intentionally violating the law, with a readiness to submit to the resulting punishment (Sokół, 1996, p. 236). Citizens who do not believe in the legitimacy of the social economy system will consciously avoid participating in the system (especially by participating in voluntary forms of association, using services offered by social economy entities, or not making donations to social organisations), even if they are aware of the fact that they do not receive specific benefits from involvement in the activities of a given social economy entity. The loss of legitimacy may also occur as a result of adverse events for the system, revealing a lack of compliance of actions with social expectations. What is important here is the social perception of the functioning of the social economy system, its institutions in particular, and not its actual functioning. Two groups of activities can be suggested here. The first group aims at bridging the legitimacy gap and demonstrating that social economy entities meet social expectations in terms of completing basic tasks - they simply provide the products or services expected by society. The second group of tools exclusively aims at improving the effectiveness (efficiency) of the system's operation; in this sense it is only about showing how the system works. It is important to carry out an appropriate information campaign on the principles of operation of individual entities and their impact on society. The legal and organisational norms that influence the way social entrepreneurship functions are not without significance. It should be noted that the so-called stratification may occur (Boxenbaum \& Jonsson, 2008), i.e., a situation where social pressure conflicts with the beliefs of those in power about what is effective (efficient) for the system or where different groups of stakeholders (social economy entities, people using social services or products, people involved in social economy entity activities) present conflicting expectations. Under such conditions, it is necessary to constantly build the legitimacy of the social economy system, especially from the point of view of individual entities operating in the system.

\section{Summary and conclusions}

Social economy entities, due to the scope of tasks and functions performed, should have a high level of legitimacy. The theory of legitimacy assumes that external stakeholders expect organisations to take such actions as allow assessment of their conduct as transparent, compliant with the law, but also as adequately satisfying the needs of society. There is no consensus as far the methods and tools for assessing the activities of social economy entities are concerned. Such an assessment should be made not only on the basis of the economic (financial) categories, but, most importantly, by establishing the interaction of a given entity with its environment. Social sector entities should provide information on their activities to create conditions for evaluating their activities, not only through the prism of assessing effectiveness and efficiency, but also through the prism of legitimacy. The introduction of the theory of legitimacy to assess the activity of social economy entities creates grounds for filling a number of gaps related to the functioning social economy reporting system. A properly adapted theory of legitimacy can fill the information, reporting, perception, and understanding gaps. The analysis of legitimacy from the perspective of social economy entities should complement the analyses of efficiency and effectiveness.

The study is theoretical in nature and was prepared on the basis of literature research. The key objective of the paper is to present the issue of legitimacy and to indicate the possibility of using the concept of legitimacy to assess the activity of social economy entities. The applied descriptive and comparative methods allowed for the development of a new view on social economy entities in terms of the legitimacy and effectiveness of the actions taken. Summarising the results of the research, it can be seen that the category of legitimacy combined with the acceptance and legal validation of the activities of individual entities, as well as the entire social economy system, can be used. In-depth research on the theory of legitimacy of the social

Efficacy / efficiency

\begin{tabular}{|c|c|c|c|}
\cline { 3 - 4 } \multicolumn{1}{c|}{} & \multicolumn{1}{c|}{ Low } & High \\
\cline { 3 - 4 } Legitimacy & High & $\begin{array}{c}\text { Stability } \\
\text { (a) }\end{array}$ & $\begin{array}{c}\text { Stability } \\
\text { (b) }\end{array}$ \\
\cline { 2 - 4 } & Low & $\begin{array}{c}\text { Instability } \\
\text { (c) }\end{array}$ & $\begin{array}{c}\text { Stability } \\
\text { (d) }\end{array}$ \\
\hline
\end{tabular}

Figure 1. Relationship between system efficiency and legitimacy 
economy sector is required. After the analysis, more questions than answers arise. Social economy entities face a challenge, not only to develop their activities, but also to strengthen the entire social economy sector in terms of quality and quantity. The need to manage the legitimacy of institutions related to social economy becomes of strategic importance. Especially in Polish conditions, it seems necessary for the development of the sector to take place by strengthening legitimacy. Legitimacy requires social economy entities to shape various elements that will strengthen social support in activities undertaken by such institutions. Legitimacy is not something that can be easily built or forced. However, it is worth undertaking research and activities aimed at finding solutions to shape a high level of legitimacy. The article is a voice in the discussion for further consideration of the issues raised.

\section{References}

Beetham, D. (1991). The legitimation of power. London.

Beuren, I. M., \& Boff, M. L. (2011). Predominant strategies of legitimacy in environmental and social disclosures. Management Research: The Journal of the Iberoamerican Academy of Management, 9(1), 56-72.

Bohdziewicz-Lulewicz, M. et al. (2012). Pomiar społecznej wartości dodanej generowanej przez podmioty ekonomii społecznej - główne dylematy i wyzwania. Ekonomia Społeczna, 2(5).

Borzaga, C., \& Tortia, E. (2007). Social economy organizations in theory of the firm. In A. Noya \& C. Emma (Eds.), Social economy: Building inclusive economies. OECD.

Boxenbaum, E., \& Jonsson, S. (2008). Isomorphism, diffusion and decoupling. In R. Greenwood, C. Oliver, R. Suddaby, \& K. Sahlin (Eds.), The Sage Handbook of Organizational Institutionalism. Sage Publishing. CEP-CMAF Charter on Social Economy, Brussels 2002, www. cepcmaf.org

CEP-CMAF. (2005). Europejska Ekonomia Społeczna (Social Economy Europe). The content of the Charter as published in: Ekonomia Społeczna, Kraków, 2004. 2nd European Social Economy Conference — Materials. Warszawa: MPiPS, ZLSP; CEP-CMAF Charter [2005] [in:] Ekonomia społeczna, II Europejska Konferencja Ekonomii Społecznej, materiały, Ministerstwo Polityki Społecznej, Związek Lustracyjny Spółdzielni Pracy, Warszawa-Kraków 2004. www.cepcmaf.org

Chodyński, A. (2017). Legitymizacja przedsiębiorstwa a triada strategicznych działań w zakresie CSR: Przedsiębiorczość - innowacyjność - jakość. ZN WSH Zarzadzania, 2017(1), 9-27. DOI: 10.5604/01.3001.0010.2870. https://sbc.org.pl/Content/295478/1-2017-9-27\%20Chodynski.pdf

Cooper S. (2004), Corporate Social Performance: A Stakeholders Approach, Ashgate, London

Czechowski, I. (1997). Wielowymiarowa ocena efektywności ekonomicznej przedsiębiorstwa przemysłowego. Wydawnictwo Uniwersytetu Gdańskiego.

Deegan, C., \& Unerman, J. (2011). Financial accounting theory. McGraw-Hill Education.

Deephouse D., \& Suchman, M. C. (2008). Legitimacy in organizational institutionalism. In R. Greenwood, C. Oliver, R. Suddaby, \& K. Sahlin (Eds.), The Sage Handbook of Organizational Institutionalism (pp. 49-78). Sage Publications.

Durocher, S., \& Fortin, A. (2010). Standard-setting institutions' user-oriented legitimacy management strategies: The Canadian case. Qualitative Research in Accounting \& Management, 7(4), 476-504

Etzioni, A. (1973). The third sector and domestic missions. Public Administration Review, 33(4), 314-323.

Frączek, M., Hausner, J., \& Mazur, S. (Eds.). (2012). Wokół ekonomii społecznej. MSAP UEK.

Furtak-Niczyporuk, M., \& Drop, B. (2013). Efektywność organizacji systemu Państwowe Ratownictwo Medyczne. In A. Frączkiewicz-Wronka (Ed.), Efektywność zarządzania organizacjami publicznymi i jej pomiar, Studia Ekonomiczne, no. 168/3, 54-67.

Głowacki, J. (2010). Mierzenie społecznej wartości dodanej. Ekonomia Społeczna, 1.

Głowacki, J., Płonka, M., \& Rosiek, K. (2012). Ocena społęczno - ekonomiczna efektów działania podmiotów ekonomii społecznej. In M. Frączek, J. Hausner, \& S. Mazur (Eds.), Wokół ekonomii społecznej. MSAP UEK.

Goleński, W. (2017). Efektywność organizacyjna podmiotów ekonomii społecznej - próba operacjonalizacji. Ekonomia Społeczna, 2017(1), 7-21. http://www.ekonomiaspoleczna.msap.pl/doki/polrocznik/ES012017/ES012017-01.pdf

Grassl, W. (2012). Business models of social enterprise: A design approach to hybridity. ACRN Journal of Entrepreneurship Perspectives, 1(1). Griffin, R. W. (2002). Podstawy zarządzania organizacjami. PWN.

Guo, C., \& Bielefeld, W. (2014). Social entrepreneurship. An evidence-based approach to creating social value. Jossey-Bass: A Wiley Brand. Hausner, J. (Ed.) Ekonomia społeczna a rozwój. Małopolska Szkoła Administracji Publicznej, Uniwersytetu Ekonomicznego w Krakowie, Kraków. http://www.msap.uek.krakow.pl/doki/publ/es_ekonomia.pdf (30.03.2020)Jastrzębska, M. (2016). Uwarunkowania pomiaru efektywności wydatków jednostek samorządu terytorialnego. Finanse, Rynki Finansowe, Ubezpieczenia, 6(84), part 1, 43-53. 
Juraszek-Kopacz, B., \& Tyrowicz, J. (2008). Zmierzyć niemierzalne, czyli o pomiarze oddziaływania społecznego. Poradnik dla organizacji pozarządowych i przedsiębiorstw społecznych. Klon/Jawor.

Kosturbiec J. (2001) Istota prawnej legitymizacja władzy, Studenckie Zeszyty Naukowe 4/5, 8-23.

Kotarbiński, T. (1982). Traktat o dobrej robocie. Wydawnictwo Zakładu Narodowego Imienia Ossolińskich, Wrocław-Warszawa-KrakówGdańsk-Łódź.

Krasodomska, J. (2013). Sprawozdawczość przedsiębiorstw w świetle legitymizacji, Studia i Prace Kolegium Zarzadzania i Finansów / Szkoła Główna Handlowa, 130, 39-51.

Kwaśnicki, W. (2005). Gospodarka społeczna z perspektywy ekonomii liberalnej. Trzeci Sektor, 2005(2), 10-35.

Łada, M. (2015). Zasoby czy osiągnięcia organizacji - wpływ procesów legitymizacyjnych na zmianę kategorii pomiaru. Studia Ekonomiczne I Zeszyty Naukowe Uniwersytetu Ekonomicznego w Katowicach, 2015(244), 110-119.

Łada, M., \& Kozarkiewicz, A. (2013). Teoria legitymizacji w badaniach z zakresu rachunkowości. Zeszyty Teoretyczne Rachunkowości, 71(127). Stowarzyszenie Księgowych w Polsce, Warszawa, 161-175.

Łącka I. (2015) Problemy oceny efektywności podmiotów ekonomii społecznej, Prace Naukowe Uniwersytetu Ekonomicznego we Wrocławiu, no 395, s. 241-251.

Lipset, S. M. (1959). Some social requisites of democracy: Economic development and political legitimacy. American Political Science Review, 53, 69-105.

Marzec, M., \& Szczudlińska-Kanoś, A. (2019). Legitimization of pension institutions. The need or necessity? [Paper]. Prace Naukowe Nauki o Zarządzaniu i Jakości, 83(9), Uniwersytet Ekonomiczny we Wrocławiu.

Matuszak, Ł. (2015). Raportowanie o społecznej odpowiedzialności przedsiębiorstw (CSR) za pomocą narzędzia legitymizacji przedsiębiorstw. Studia Oeconomica Posnaniensia, 3(1), 112-134.

Ministerstwo Rodziny, Pracy i Polityki Społecznej. (2019). <Title> (Monitor Polski of 2019, item 214). Biblioteka Ekonomii Społecznej i Solidarnej. Retrieved March 30, 2020 from https://www.ekonomiaspoleczna.gov.pl/download/files/EKONOMIA_SPOLECZNA/KPRES.pdf

Ogden, S., \& Clarke, J. (2005). Customer disclosures, impression management and the construction of legitimacy: Corporate reports in the UK privatised water industry. Accounting, Auditing \& Accountability Journal, 18(3), 313-345. https://doi.org/10.1108/09513570510600729

Oliver, C. (1991). Strategic responses to institutional processes. Academy of Management Review, 16, 145-179.

Penc, J. (1997). Leksykon biznesu. Placet.

Pfeffer, J. (1981). Management as symbolic action: The creation and maintenance of organizational paradigms [<Master's thesis,> Graduate School of Business, Stanford University].

Płonka, M. (2008a) Dylematy finansowania podmiotów ekonomii społecznej. Ekonomia Społeczna, 2008(1), $24-32$.

Płonka, M. (2008b). Wybrane problemy rachunku kosztów i korzyści społecznych podmiotów ekonomii społecznej. Ekonomia Społeczna, 2008(2), 26-34.

Płonka, M. (2008c), Zarządzanie podmiotami ekonomii społecznej - relikt przeszłości czy istotny kierunek przyszłości. In D. Fatuła (Ed.), Zarządzanie rozwojem ekonomicznym. Wybrane aspekty (pp. 185-199), Kraków.

Płonka, M. (2009). Sektor ekonomii społecznej, jego miejsce i funkcje w gospodarce rynkowej. In D. Surówka-Marszałek (Ed.), Marketing, Acta Academiae Modrevianae. Kraków: Krakowskie Towarzystwo Edukacyjne sp. z o.o. — Oficyna Wydawnicza AFM.

Płonka M. (2015) Ekonomia społeczna a koncepcje polityki społecznej państwa. Model polski. Ekonomia Społeczna no. 2/2015, p. 85-100. DOI: 10.15678/ES.2015.2.06

Pyszka, A. (2015). Istota efektywności. Definicje i wymiary. Studia Ekonomiczne. Zeszyty Naukowe Uniwersytetu Ekonomicznego w Katowicach, no. 230, 14-28.

Sokół W.(1995)Legitymizacja systemu politycznego - jako kategoria analityczna, Annales Universitatis Marie Curie-Skłodowska Lublin - PoIonia, Vo. II/III, Sectio K, 1995/1996.

Stanienda, J., Gądek, A., \& Płonka, M. (2017). Przedsiębiorczość społeczna. Nauka — praktyka - edukacja. Tarnów. Retrieved March 30, 2020 from http://www.propublicobono.info/files/publikacje/Przedsiębiorczość\%20społeczna.pdf

Stiglitz, J., Sen, A. K., \& Fitoussi, J. P. (2009) The measurement of economic performance and social progress revisited: Reflections and overview, OFCE, no. 2009-33.

Stoner, J. A. F., Freeman, R. E., \& Gilbert, D. R. (Eds.). (2001). Kierowanie. PWE.

Suchman, M. C. (1995), Managing legitimacy: Strategic and institutional approaches. Academy of Management Review, 20(3), 571-610.

Supernat, J. (2005). Zarządzanie. Kolonia Limited.

Szymańska, E. (2010). Efektywność przedsiębiorstw — definiowanie i pomiar. Roczniki Nauk Rolniczych, Series G, 97(2).

Szymczak, M. (Ed.). (1988). Słownik języka polskiego. PWN.

Tokarski, J. (Ed.). (1978). Słownik wyrazów obcych. PWN.

Urbano, D., Toledano, N., \& Soriano, D. R. (2010). Analyzing social entrepreneurship from an institutional perspective: Evidence from Spain. Journal of Social Entrepreneurship, 1(1). 
Wesołowski, W. (2001). Legitymizacja jako potoczna filozofia władzy. Studia Socjologiczne, 2(161), 5-35.

Winczorek, P. (1985). Legitymizacja władzy politycznej. Państwo i Prawo, 1985(11).

Zahra, S. A., Gedejovic, E., Neubaum, D. O., \& Shulman, J. M. (2009). A typology of social entrepreneurs: Motives, search processes and ethical challenges. Journal of Business Venturing, (24)5, 519-532.

Zieleniewski, J. (1991) Organizacja i zarządzanie. Polskie Wydawnictwo Naukowe.

Zieliński, M. (2013). Efektywność - ujęcie ekonomiczne i społeczne. Zeszyty Naukowe Politechniki Śląskiej, Organizacja i Zarządzanie, 66(1898), 1-12.

Żyłomski, M. (2012). Legitymacja czy legitymizacja władzy. Doświadczenia państw Europy Środkowej. Środkowoeuropejskie Studia Polityczne, 2012, no. 3, Wydawnictwo Naukowe WNPiD UAM w Poznaniu, p. 19. https://repozytorium.amu.edu.pl/handle/10593/8046

Zysnarska-Dworzak B. (2015). Zrównoważona rachunkowość zarządcza w świetle teorii legitymizacji. Zeszyty Teoretyczne Rachunkowości, Stowarzyszenie Księgowych w Polsce, 82(138), 2015, 181-189. 